\title{
Citation analysis of Acta Dermatovenerologica Alpina, Pannonica et Adriatica: 1992-2013
}

\author{
Anja Oštrbenk ${ }^{1}$, Mario Poljak ${ }^{\circledR}$
}

\begin{abstract}
Acta Dermatovenerologica Alpina, Pannonica et Adriatica is the leading journal in the field of dermatology and sexually transmitted infections in the region. Several important steps were taken during the last 20 years to improve the journal's quality, global visibility, and international impact. Since 1992, 699 bibliographical items have been published, which received 1,360 citations. Web of Science citable items received on average 2.29 citations per item. Importantly, almost half (49.6\%) of all citations retrieved to date were received from 2012 onwards. The predicted impact factor was calculated in a way to match official impact factors published annually in Thomson Scientific Journal Citation Reports. Citation analysis shows a substantial increase of the predicted impact factor since 2006, with values above 0.5 since 2007 . For the first time in the journal's history, a predicted impact factor value above 1.0 was recorded in 2013.
\end{abstract}

Keywords: Acta Dermatovenerologica Alpina, Pannonica et Adriatica, citation analysis, impact factor

Received: 13 February 2015 | Returned for modification: 18 February 2015 | Accepted: 26 February 2015

\section{Introduction}

The journal Acta Dermatovenerologica Alpina, Pannonica et Adriatica (Acta Dermatovenerol APA) was founded in 1992 in Ljubljana by Aleksej Kansky, who was also the journal's first editor-in-chief. Over more than two decades of publishing, the journal and its editors experienced many challenges, as described in detail previously (1-6). In order to improve the quality and to establish its international recognition, several crucial steps were taken. The international visibility significantly increased after 2000, when the journal implemented an online open access policy in addition to the printed version. Since then, the entire content of Acta Dermatovenerol APA has been freely available at the journal's official website, http://www.acta-apa.org/. A major accomplishment occurred in 2005, when the journal achieved full indexing status in Index Medicus/Medline in addition to Biomedicina Slovenica and EMBASE/Excerpta Medica. Thus, from volume 14 onwards, the entire content of the journal has been included in PubMed, the most important bibliographic database for medical journals. In 2012, we significantly redesigned the journal's structure and appearance, in line with modern standards for a European journal. During 2014, we fundamentally redesigned the journal's website, including digitalization of all 699 contributions published since 1992, which are now freely available in the full text on the journal's official website (http://www.acta-apa.org/journals/actadermatovenerol-apa/archive). Recently, several steps were taken to further increase the journal's quality and to reach the next important goal in the journal's development: official indexing of the journal in the Thomson Scientific Science Citation Index. To foster this goal, we present here the most recent citation analysis (1992-2013), which accompanies two citation analyses published previously $(4,6)$.

\section{Methods}

The citation analysis comprised all bibliographical items pub- lished in Acta Dermatovenerol APA from 1992 to 2013. To optimize publication patterns according to the official Thomson Scientific Web of Science (WoS) publication types, the journal's original publication types were reclassified and divided into WoS citable and WoS noncitable items, using methodology described in detail previously $(4,6,7)$. Citation analysis was performed manually and separately for each bibliographical item through a Cited Reference search of the WoS electronic database on 13 February 2015. Citations retrieved in this analysis were merged with citations obtained in two previous citation analyses published in 2009 and 2012, analyzing the time periods 1992-2008 and 1992-2011, respectively $(4,6)$.

For all 22 individual years (1992-2013), predicted impact factors were calculated. The predicted impact factor reflects the average number of citations of articles published, based on the number of citable items published and citations retrieved. Calculation of the predicted impact factor was done in a way to match official impact factors published annually in Thomson Scientific Journal Citation Reports. The journal impact factor in the year X is defined as the ratio of the number of citations received in year $\mathrm{X}$ by all published items in the journal in the years X - 1 and X - 2 (value A, Table 1) and the sum of published WoS citable items in the journal in the years X - 1 and X - 2 (value B, Table 1). For example, the predicted impact factor for 2013 is calculated as the ratio of the number of citations received in 2013 by all published items in the journal in 2012 and 2011 and the sum of published WoS citable items in the journal in 2012 and 2011.

\section{Results}

As summarized in Table 1, as of 13 February 2015, 699 bibliographical items were published in Acta Dermatovenerol APA from 1992 to 2013, including 435 articles, 148 reviews, 51 meeting summaries, 32 letters, 12 items about an individual, 11 book reviews, 8 editorials and 2 meeting abstracts. Among these, 582 (83.3\%) were considered WoS citable items and 117 (16.7\%) as WoS noncitable 
Table 1 | Results of citation analysis of bibliographical items published in Acta Dermatovenerologica Alpina, Pannonica et Adriatica $1992-2013$.

\begin{tabular}{|c|c|c|c|c|c|c|c|}
\hline Publication year & $\begin{array}{l}\text { Total number of } \\
\text { published items }\end{array}$ & $\begin{array}{c}\text { Total number of } \\
\text { WoS citable items }\end{array}$ & $\begin{array}{l}\text { Total number of } \\
\text { received citations }\end{array}$ & $\begin{array}{l}\text { Total number of } \\
\text { received independent } \\
\text { citations }\end{array}$ & $\begin{array}{l}\text { A value for IF } \\
\text { calculation }\end{array}$ & $\begin{array}{l}\text { B value for IF } \\
\text { calculation }\end{array}$ & $\begin{array}{l}\text { Predicted IF } \\
\text { (A/B) }\end{array}$ \\
\hline 1992 & 28 & 20 & 20 & 17 & I & 1 & 1 \\
\hline 1993 & 30 & 24 & 4 & 3 & l & l & l \\
\hline 1994 & 36 & 32 & 35 & 31 & 3 & 44 & 0.068 \\
\hline 1995 & 41 & 36 & 11 & 9 & 3 & 56 & 0.054 \\
\hline 1996 & 39 & 30 & 23 & 17 & 2 & 68 & 0.029 \\
\hline 1997 & 26 & 22 & 1 & 1 & 2 & 66 & 0.030 \\
\hline 1998 & 29 & 25 & 12 & 12 & 1 & 52 & 0.019 \\
\hline 1999 & 32 & 25 & 18 & 14 & 0 & 47 & 0.000 \\
\hline 2000 & 30 & 22 & 16 & 15 & 5 & 50 & 0.100 \\
\hline 2001 & 32 & 26 & 29 & 16 & 2 & 47 & 0.043 \\
\hline 2002 & 25 & 23 & 20 & 14 & 2 & 48 & 0.042 \\
\hline 2003 & 29 & 24 & 17 & 17 & 6 & 49 & 0.122 \\
\hline 2004 & 29 & 22 & 37 & 30 & 2 & 47 & 0.043 \\
\hline 2005 & 30 & 26 & 180 & 167 & 2 & 46 & 0.043 \\
\hline 2006 & 36 & 27 & 144 & 138 & 17 & 48 & 0.354 \\
\hline 2007 & 38 & 31 & 232 & 218 & 30 & 53 & 0.566 \\
\hline 2008 & 34 & 31 & 194 & 189 & 29 & 58 & 0.500 \\
\hline 2009 & 40 & 34 & 143 & 133 & 55 & 62 & 0.887 \\
\hline 2010 & 37 & 34 & 87 & 84 & 49 & 65 & 0.754 \\
\hline 2011 & 33 & 31 & 101 & 91 & 42 & 68 & 0.618 \\
\hline 2012 & 23 & 20 & 24 & 23 & 33 & 65 & 0.508 \\
\hline 2013 & 20 & 17 & 12 & 11 & 52 & 51 & 1.020 \\
\hline Total & 699 & 582 & 1,360 & 1,250 & 1 & 1 & 1 \\
\hline
\end{tabular}

items. A total of 1,360 SCI citations were retrieved from the WoS cited reference search and, as shown in Table 1, 1,250 (91.9\%) were considered to be independent citations and $110(8.1 \%)$ to be author self-citations.

Among 699 items published, 582 (83.3\%) WoS citable items received a total of 1,333 out of 1,360 citations retrieved, or on average 2.29 citations per published item. A detailed analysis of the main citation indicators of bibliographical items published in the period 1992-2013 in comparison to two previous citation analysis performed in 2009 (period 1992-2008) and in 2012 (period 1992-2011) is shown in Table 2. Briefly, as of 13 February 2015, 298 $(51.2 \%)$ WoS citable items published in our journal had received at least one SCI citation, 124 (21.3\%) items had received four or more SCI citations, and $284(48.8 \%)$ items are still without a single citation. As shown in Table 2, in comparison to the period 1992-2008, in the period 1992-2013 the proportion of WoS citable items that received at least one SCI citation increased from $34.3 \%$ to $51.2 \%$, respectively, and the proportion of WoS citable items that received four or more SCI citations increased from 3.1\% to $21.3 \%$, respectively. Among 117 WoS noncitable items published in our journal, 11 (9.4\%) items received at least one SCI citation, with a total of 27 citations received, or on average 0.23 citations per published item (Table 2).

Among all published bibliographical items, the most cited contribution was a review by Rožman and Bolta published in 2007 entitled "Use of platelet growth factors in treating wounds and softtissue injuries," with 68 citations received as of 13 February 2015.

As shown in detail in Figure 1, citation analysis showed a substantial increase in the predicted impact factor since 2006, with values above 0.5 since 2007. For the first time in the journal's history, a predicted impact factor value above 1.0 was recorded in 2013 (Fig. 1).

\section{Discussion}

Our citation analysis revealed that the majority of published items in our journal can be considered WoS citable items. As of 13 Feb-

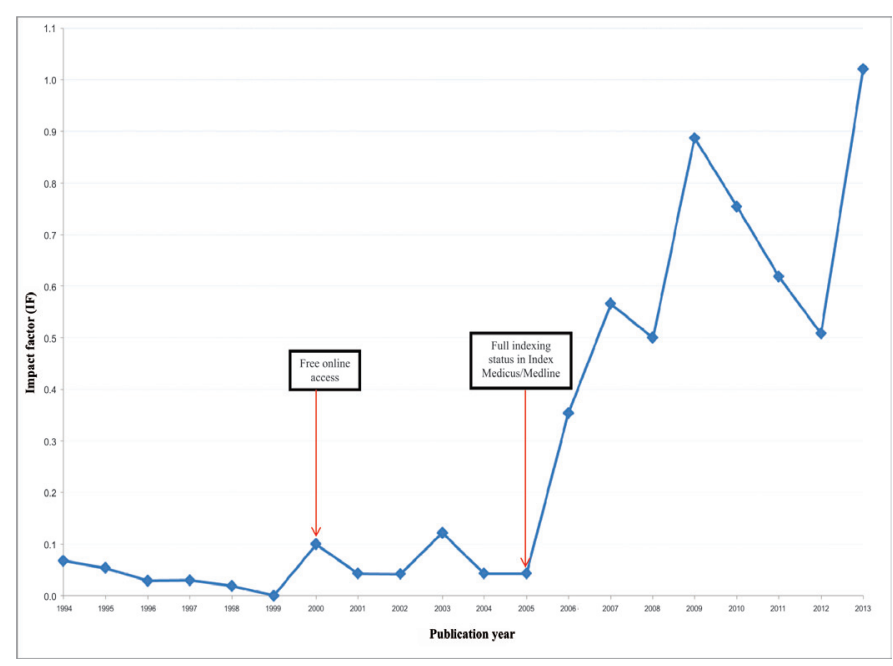

Figure 1 | Predicted impact factor of Acta Dermatovenerologica Alpina, Pannonica et Adriatica from 1992 to 2013.

ruary 2015, WoS citable items received an average of 2.3 citations per item. In comparison to the data published earlier $(4,6)$, the proportion of WoS citable items remains similar through all three time periods evaluated (1992-2008, 1992-2011, and 1992-2013); however, WoS citable items received on average 3.4 more citations per item during 1992-2013 in comparison to the 1992-2008 period (2.29 vs. 0.67 ) and 2.4 more citations per item in comparison to the 1992-2011 period (2.29 vs. 0.97). A similar dynamic was also recorded for WoS noncitable items, with 0.05, 0.12, and 0.23 average citations per item during 1992-2008, 1992-2011, and 1992-2013, respectively (Table 2). These figures are a result of a recent dramatic increase in the total number of SCI citations, with almost half $(49.6 \%)$ of all citations received from January 2012 onwards.

The proportion of author self-citations among all citations received is comparable to other leading research journals (8), with an encouraging decreasing trend of author self-citations from $18.2 \%$ during $1992-2008$ to $8.1 \%$ during 1992-2013. Alongside author self-citation (9), journal self-citation is one of the most common ways in which journals artificially improve their impact fac- 
tor (10-12). We are proud that for Acta Dermatovenerol APA only a few journal self-citations were identified in this analysis.

Regardless of the fact that the impact factor was primarily developed as a bibliographical tool $(13,14)$ it is still the most frequently used index for measuring the research quality of individuals, research groups, and institutions (15). Although it is often criticized as unrepresentative, misleading, and easily manipulated, a journal's impact factor remains of high importance for both authors and editors $(7,16-18)$. For the purpose of citation analysis of our journal, a very conservative and stringent approach for the "in house" calculation of the predicted impact factor was used (mainly for classification of WoS citable items), as described in detail previously $(4,6)$. Thus, we strongly believe that the predicted impact factors calculated in our analysis are a fairly good estimation (and most probably an underestimation) of the official impact factors that would be published in the annual Thomson Scientific Journal Citation Reports. As already described in our previous cita- tion analysis (6), the free online access policy of our journal established in 2000 surprisingly did not have any measurable impact on the predicted impact factor. On the other hand, a substantial increase of the predicted impact factor occurred in 2006, immediately after achieving full indexing status in Index Medicus/Medline.

As shown in Figure 1, our analysis showed positive dynamics of the predicted impact factor of Acta Dermatovenerol APA, with values above 0.5 since 2007 and, for the first time in the journal's history, a value above 1.o recorded in 2013. With its 2012 and 2013 predicted impact factors, Acta Dermatovenerol APA would be ranked 54th out of 59 and 45th out of 61 journals listed in the category “Dermatology” for 2012 and 2013, respectively, according to Thomson Scientific Journal Citation Report Science Edition. We sincerely hope that the recent significant quality improvements of our journal will soon also be acknowledged by Thomson Scientific by indexing our journal in the Science Citation Index and rewarded by the journal's first official impact factor.

Table 2 | Main citation indicators of bibliographical items published in Acta Dermatovenerologica Alpina, Pannonica et Adriatica over three time periods.



\section{References}

1. The Editors. Editorial 2006. Acta Dermatovenerol Alp Panonica Adriat. 2006;15:3-4

2. Kansky A. Acta Dermatovenerologica Alpina, Pannonica et Adriatica: At the occasion of 10th anniversary. Acta Dermatovenerol Alp Panonica Adriat. 2002; 11:133-6.

3. Poljak M. Editorial: Acta Dermatovenerologica Alpina, Pannonica et Adriatica and scientific misconduct. Acta Dermatovenerol Alp Panonica Adriat. 2009;18:91-3.

4. Poljak M, Oštrbenk A. Editorial: Citation analysis of Acta Dermatovenerologica Alpina, Pannonica et Adriatica 1992-2008. Acta Dermatovenerol Alp Panonica Adriat. 2009;18:147-51.

5. Poljak M, Žiberna K, Ilovar S, Luzar B, Miljković J. Editorial: The 2oth anniversary of Acta Dermatovenerologica Alpina, Pannonica et Adriatica: New clothes for a young lady. Acta Dermatovenerol Alp Panonica Adriat. 2012;21:1.

6. Oštrbenk A, Škamperle M, Poljak M. Citation analysis of Acta Dermatovenerologica Alpina, Pannonica et Adriatica 1992-2011. Acta Dermatovenerol Alp Panonica Adriat. 2012;21:47-9.

7. Wu XF, Fu Q, Rousseau R. On indexing in the Web of Science and predicting journal impact factor. J Zhejiang Univ Sci B. 2008;9:582-90.

8. Falagas ME, Kavvadia P. "Eigenlob": self-citation in biomedical journals. FASEB J. 2006;20:1039-42.
9. Liu XL, Wang MY. Self-citation in Chinese biomedical journals. Learn Publ. 2010; 23:93-100.

10. Kovačić N, Huić M, Ivaniš A. Citation analysis of the Croatian Medical Journal: the first 15 years. Croat Med J. 2008;49:12-7.

11. Fassoulaki A, Papilas K, Paraskeva A, Patris K. Impact factor bias and proposed adjustments for its determination. Acta Anaesthesiol Scand. 2002;46:902-5.

12. Falagas ME, Alexiou VG. The top-ten in journal impact factor manipulation. Arch Immunol Ther Exp. 2008;56:223-6.

13. Garfield E. The history and meaning of the journal impact factor. JAMA. 2006; 295:90-3.

14. Garfield E. Use of Journal Citation Reports and Journal Performance Indicators in measuring short and long term journal impact. Croat Med J. 2000;41:368-74.

15. Garfield E. Impact factors, and why they won't go away. Nature. 2001;31:522.

16. Brown H. How impact factors changed medical publishing-and science. BMJ. 2007;334:561-4

17. Anon. Not-so-deep impact. Nature. 2005;435:1003-4.

18. Golubic R, Rudes M, Kovacic N, Marusic M, Marusic A. Calculating impact factor: how bibliographical classification of journal items affects the impact factor of large and small journals. Sci Eng Ethics. 2008;14:41-9. 